\title{
Krims historie: Fra Djengish Kahn til Putin
}

\author{
Af Ib Faurby
}

De tilsyneladende vellykkede autonomiforhandlinger $i$ anden halvdel af 1990'erne fik nogle til at se Krim som et eksempel på, at etnisk-nationale problemer lod sig løse gennem forhandling og gensidig hensyntagen. Men den britiske historiker og journalist Anna Reid skrev i 1997: 'Hvis en borgerkrig skulle bryde ud i Ukraine, så ville det mest sandsynlige være, at den begyndte på Krim'

Krim har i århundreder - ja i årtusinder - haft en dramatisk historie præget af folkevandringer, krige og erobringer. Set i russisk perspektiv var en afgørende begivenhed, at storfyrst Volodymyr af Kiev i 988 lod sig døbe og efterfølgende tvangsdøbte Kievs befolkning i Dnjeprfloden. Den byzantinske munk Kyrillos skabte det kyrilliske alfabet, og en oversættelse af bibelen til folkesproget (modsat Romerkirkens latin) betød, at den ortodokse kristendom kunne udbredes til hele det slaviske område.
I begyndelsen af 1200-tallet erobrede Djengish Kahn og hans barnebarn Batu store dele af Asien og det østlige Europa. Krim blev plyndret i 1222-23 og igen hærget i 1238. Mongolernes erobringer førte til oprettelsen af Den Gyldne Horde, der eksisterede de næste ca. 250 år.

Da Den Gyldne Horde i 1440'erne gik i opløsning, opstod i dens sted et antal selvstændige khanater, deriblandt i 1443 Krim Khanatet, der i 1475 blev et osmannisk protektorat, men dog stadig med en betydelig autonomi. Krim Khanatet var i en årrække en af de stærkeste 'stater' i det østlige Europa og foretog flere erobringstogter ind i steppeområderne mod nord, ja helt til Moskva. I begyndelsen af 1500-tallet byggede Khan Mengli Giraj sit palads i Bakhtjisaraj, der blev hovedestaten på Krim (eller Qirim på tatarisk).

1700-tallet var præget af flere krige mellem Det Osmanniske Rige og det ekspanderende Rusland. Under ledelse af Katarina den Stores elsker og reelle medregent, Grigorij Potemkin (173991), erobrede Rusland områderne ned mod Sortehavet, inkl. i 1783 Krim, der

Ib Faurby er tidligere lektor i international politik på Institut for Statskundskab ved Aarhus பniversitet. Han har desuden været sekretariatschef for Det Sikkerheds- og Nedrustningspolitiske Udvalg og medlem af dets formandskab. Han var været skribent på Politiken og derefter chefkonsulent ved Forsvarsakademiet og leder af Forsvarschefens Sikkerhedspolitiske Kursus. 
i 1796 blev inkorporeret i Novorossija ('Det nye Rusland'). Sevastopol var fra naturens side den perfekte base for den flåde, Rusland ønskede at opbygge i Sortehavet. I 1787 foretog Katarina sin berømte rejse ned ad Dnjepr for at besigtige den nye besiddelse. Efter en del ændringer blev Krim til guvernementet Tavrida efter den græske betegnelse Tauris.

Der gennemførtes en hårdhændet russificering med forfølgelse af tatarer og ødelæggelse af moskeer. Ved annekteringen boede der omkring en halv million tatarer på Krim. Flere end 100.000 flygtede i de umiddelbart følgende år til Det Osmanniske Rige. Russere, ukrainere, tyskere og andre blev inviteret til at bosætte sig, så halvøen og områderne umiddelbart nord for kunne befolkes og opdyrkes.

\section{Dødens Dal}

Strategisk drejede Krim-krigen (1853-56) sig slet ikke om Krim, men om magtbalancen mellem stormagterne i en situation, hvor Det Osmanniske Rige var i tilbagegang og et selvbevidst Rusland forsøgte at ekspandere i de hidtidige osmanniske områder. Den russiske fremtrængen på Balkan blev set som en trussel mod Istanbul, hvorfra Rusland i givet fald kunne kontrollere indog udsejlingen til Sortehavet. Storbritannien og Frankrig ville standse den russiske ekspansion, hvad der fik de to traditionelle rivaler til at indgå en skrøbelig alliance og alliere sig med osmannerne, som de egentlig ikke havde hverken sympati eller respekt for.

Da de russiske styrker gik over Donau og ind i Valakiet og Moldavien, mobiliserede Frankrig og Storbritannien og sendte militære styrker til Varna på Sortehavets vestkyst. Truslen og det neutrale Østrigs forsøg på mægling fik russerne til at trække sig tilbage, men for sent. De allierede ville ikke stille sig tilfredse med den udgang på konflikten. Krigen måtte gå sin gang. Sevastopol med den store havn og Ruslands sortehavsflåde blev målet.
Krigen foregik dog ikke kun på Krim. Der var britiske flådeoperationer i Østersøen, mindre kampe i Kaukasus, og en træfning mellem britiske og russiske flådestyrker så langt væk som ved Sakhalin. Selv ved indsejlingen til Sydney udbyggede det britiske forsvar kanonstillingerne for at kunne forsvare byen mod et evt. russisk flådeangreb.

I Danmark er Krim-krigen først og fremmest kendt gennem den omfattende britiske litteratur om krigen. Men det var franskmændene og tyrkerne, der havde flest soldater i krigen. Der findes kun en meget begrænset oversat russisk litteratur om krigen. På dansk har vi dog den unge artilleriløjtnant Lev Tolstojs Fortællinger fra Sevastopol. Den første, præget af national begejstring, behagede tsar Nikolaj I; de senere med beskrivelse af officerernes arrogance og inkompetence behagede ikke hoffet i Skt. Petersborg.

Det britiske kontingent af landstyrker var det mindste (når bortses fra Sardiniens) til de allieredes indsats. Alligevel blev den britiske Lord Ragland styrkens øverstkommanderende, selvom han aldrig havde kommanderet mere end en bataljon i felten. Han blev valgt takket være sin sociale position, franskkundskaber og manglen på et alternativ.

Forsvaret af Sevastopol blev ledet af Fyrst Menshikov og general Gortjakov. Af frygt for briternes og franskmændenes flåder sænkede russerne deres krigsskibe ved indsejlingen til Sevastopol. Om dagen bombarderede de allierede fæstningen Malakhov og skanserne foran; om natten blev skanserne genetableret under ledelse af den tysk-baltiske oberst med det passende navn Eduard Totleben. Bedst kendt er det katastrofale britiske rytteriangreb, 'The Charge of the Light Brigade', i 'Dødens Dal' mod de russiske kanonstillinger. Efter 349 dages belejring lykkedes det endelig de allierede at indtage Sevastopol.

Krim-krigen blev den blodigste mellem Napoleonskrigene og Første Verdens- 
krig. Omkring 650.000 personer, heraf ca. 475.000 russere, omkom. De franske tab var på 95.000 (heraf 75.000 pga. sygdom); briterne mistede 22.000 (dog kun 4.000 i kamp); osmannernes tab er usikre pga. mangelfuld statistik, men vurderes som dobbelt så store som briternes. Endelig mistede Sardinien ca. 2.000 mand, dog kun 28 som følge af kamphandlinger.

De store tab skyldtes først og fremmest kolera, tyfus, dysenteri og malaria - samt det helt utilstrækkelige militære sundhedsvæsen. Florence Nightingale drev et hospital i Scutari i Tyrkiet og var på flere inspektionsrejser på Krim, men deltog ikke i behandling i felten af sårede. Det gjorde til gengæld franske, katolske nonner, som den anglikanske Nightingale foragtede.

Fredsslutningen i Paris i 1856 afspejlede det russiske nederlag. De langsigtede konsekvenser af krigen blev sammenbruddet af 'Den Europæiske Koncert' og dermed begyndelsen på de modsætninger og den ustabilitet, der pegede frem mod Første Verdenskrig.

\section{Juvelen i Imperiets Krone}

Trods krigen blev Krim, eller mere præcist sydkysten, i løbet af 1800-tallet det mondæne feriested for tsar-familien, adelen og det bedre borgerskab; Ruslands modstykke til Côte d’Azur.

Allerede før Krim-krigen havde grev Mikhail Vorontsov, generalguvernør over 'Det Nye Rusland, bygget sit imposante sommerslot i Alupka lidt vest for Jalta. I slutningen af århundredet fuldførte tsar Aleksander III Massandra, der blev hans vinslot og lagde navn til berømte hedvine. Mange år senere blev det en af Stalins foretrukne datjaer. Feliks Jusupov, der sammen med en medsammensvoren i 1916 myrdede Grigorij Rasputin, havde paladset Koreiz, hvor Stalin boede under Jalta-konferencen i 1945. Livadia var tsarfamiliens gamle sommerbolig. Nikolaj II lod et nyt Livadia bygge, der stod færdigt i 1911 og nok er det smukkeste af slottene. Det var her Jalta-konferencen blev afholdt.

I 1821 besøgte Aleksandr Pusjkin, Ruslands store romantiske digter, under sin meget milde forvisning til 'Det Nye Rusland', Krim. Det resulterede i hans berømte digt 'Fontænen i Bakhtjiseraj'.

Tuberkulose var en af det 19. århundredes svøber, der ramte høj såvel som lav. Mange syge, der havde råd, opsøgte det milde klima på Krims sydkyst. Én af dem var lægen og forfatteren Anton Tjekhov (1860-1904). Mellem alle Krims imposante paladser er Anton Tjekhovs 'hvide datja, oprindelig bygget i en tatarisk landsby i udkanten af Jalta, et af halvøens mest charmerende steder. Det var her, han skrev teaterstykkerne 'Tre Søstre' og 'Kirsebærhaven'. Blandt novellerne er 'Dame med hund', der delvis foregår på Jaltas havnepromenade.

Ved bordet $\mathrm{i}$ forstuen mødtes mange af tidens forfattere. Bl.a. den 'aristokratiske', senere ledende eksilforfatter i Paris og nobelprismodtager Ivan Bunin, og hans modstykke, den unge 'proletarforfatter' Maxim Gorkij, der til stor vrede for det politiserede litterære parnas i Moskva, aldrig fik nobelprisen. Tjekhov læste Gorkijs udkast og vejledte den iltre unge mand. Sammen med Tjekhov besøgte han også den store mand i russisk litteratur, Lev Tolstoj, der på sine gamle dage ferierede lidt længere henne ad kysten i Gaspara. På første sal i Tjekhovs datja står et klaver, som Sergej Rachmaninov formentlig spillede på, når han besøgte vennen.

En anden forfatter, hvis navn er uløseligt forbundet med Krim, er Maksimilian Voloshin (1877-1932). I slutningen af 1920'erne faldt han i politisk unåde og opnåede først anerkendelse igen i 1960'erne. I hans hus i Koktebel med udsigt over havet mødtes mange af tidens 'sølvalderforfattere', bl.a. Marina Tsvetajeva, Osip Mandelstham, Ilja Ehrenburg og Mikhail Bulgakov. Voloshin var også maler. Især hans stemnings- 
fulde akvareller bidrog til en opfattelse af et fredeligt, men også lidt mystisk Krim.

Den mest berømte maler er dog den russisk-armenske 'marinemaler' Ivan Aivazovskij (1817-1900) fra Feodosia. Mere end nogen anden kunstner har han formet russernes, armeniernes og andre forestillinger om Krims sydkyst og Sortehavets vælde. Han var ekstremt flittig, og hans værker hænger på såvel storby- som provinsmuseer overalt i det tidligere Sovjetunionen.

\section{Mavesåret Krim}

Efter revolutionen i oktober 1917 begyndte borgerkrigen mellem bolsjevikkernes Røde Hær og 'de hvide' monarkister. Mange tilhængere af tsarstyret og andre modstandere af bolsjevikkerne flygtede til Krim, deriblandt enketsarina Marija Fjodorovna ('Dronning Dagmar').

De hvide i Nordvestrusland og Sibirien blev slået af Den Røde Hær, og i april 1920 blev resterne af general Anton Denikins 'Sydruslands Væbnede Styrker' i Kaukasus tvunget til at evakuere over Kertj-strædet til Krim. Her tog general, baron Petr Wrangel (af bolsjevikkerne kaldet den 'Sorte Baron') magten og skabte ud af resterne af Denikins hær samt Don-kosakker og lokale styrker, hvad han betegnede 'Den Russiske Hær'. Ligesom Denikin var han diktatorisk, men samtidig en mere professionel militær leder og havde større sans for befolkningens behov.

Geografien var på Wrangels side, da Krim kun var forbundet med fastlandet med den smalle Perekop-landtange, og bolsjevikkerne havde ingen flådestyrker i Sortehavet. Samtidig var bolsjevikkerne involveret i krig med Polen. Styrkeforholdet var dog ikke til Wrangels fordel. I juni 1920 stod han med en hær på 30.000-35.000 regulære soldater. Den Røde Hær var på fem mio. mand. Wrangels mål var at støde op langs vestbredden af Dnepr-floden og skabe forbindelse til de polske styrker. Det lykkedes dog ikke.

Storbritannien, der havde støttet de hvi- de med penge og materiel, havde for længst indset, at det var forgæves og havde i efteråret 1919 indstillet støtten. Så da krigen med Polen var forbi, kunne bolsjevikkerne koncentrere sig om opgøret med 'mavesåret', som de kaldte Krim. Mikhail Frunze, en af Den Røde Hærs mest erfarne ledere, blev sat i spidsen for en styrke på 133.000 mand, der skulle nedkæmpe den sidste hvide styrke. Wrangel var nær ved at blive omringet nord for Krim, men det lykkedes ham at nå tilbage og tage opstilling med sin styrke på Perekop-landtangen. En bolsjevikisk overraskelsesoperation over den lavvandede Sivash-saltsø på den østlige side, afgjorde imidlertid slaget om Krim.

Nederlaget var uundgåeligt, men Wrangel havde stadig kontrol over Krims havne. Herfra gennemførte han i november 1920 en enestående evakuering af 146.000 soldater og civile med store og små skibe til Konstantinopel. Allerede den 11. april 1919 var Marija Fjordorovna med følge blevet evakueret på det britiske krigsskib HMS 'Marlborough'.

Ifølge Lenin var der dog stadig 300.000 'borgerlige' og tilhængere af de hvide tilbage på Krim. Den ungarske kommunist Bela Kun blev sat i spidsen for deres 'genopdragelse'. Omkring 60.000 personer af alle folkeslag blev udryddet, inden Lenin kaldte Bela Kun tilbage til Moskva, hvor han i øvrigt blev henrettet i 1939 for 'trotskisme'.

'Man kan ikke lave omelet uden at slå æg i stykker'. Dette var efter sigende Stalins kyniske bemærkning om udryddelsen af kulakkerne, tvangskollektiviseringen og den politisk planlagte og gennemtvungne hungersnød i Ukraine i 1932-33. Ifølge historikeren Robert Conquest kostede 'afkulakkiseringen' 6,5 millioner og tvangskollektiviseringen fire millioner ukrainere livet. Antallet af omkomne på Krim kendes ikke, men det var betydeligt. Et stort antal tatarer blev deporteret, og i 1954 blev ca. 9.000 ukrainske bønder tvangsforflyttet til Krim for at kompensere for de deporterede tatarer. 
lede sig en karakteristisk sovjetisk by med brede boulevarder og imposante bygninger. Lokale partiledere og arkitekter ønskede derimod at genskabe så meget som muligt af det historiske Sevastopol. Efter langstrakte forhandlinger lykkedes det de lokale at trænge igennem med flere af deres krav. Så selv om byen fik sine karakteristiske sovjetiske monumenter og bygninger, så blev betydelige dele af den historiske arv genetableret og gjorde Sevastopol til noget nær et udendørs historisk museum.

Krigens ødelæggelser fik Winston Churchill til i februar 1945 at kalde sydkysten for 'Dødsrigets Riviera'. Slotte og paladser langs kysten var dog ikke så stærkt beskadiget som Sevastopol. Von Manstein, havde indlogeret sig i Livadia, tsarens tidligere sommerpalads, og ved et lykketræf blev det en tysk officer med litterære interesser, der boede i Tjekhovs datja.

\section{Myten om Jalta}

En af de mest hårdnakkede myter $\mathrm{i}$ Vesten er, at 'de tre store' - Stalin, Roosevelt og Churchill - delte Europa på Jalta-konferencen i februar 1945. Men det gjorde de ikke. Der er intet i de officielle dokumenter fra konferensen, der bekræfter påstanden. Myten om Jalta blev skabt i et ejendommeligt makkerskab mellem den republikanske højrefløj i USA og revisionistiske historikere i USA og Vesteuropa.

Jalta-konferensen var et møde i begyndelsen af februar 1945 mellem en sejrrig og sejrsikker Stalin, en udmattet Churchill og en syg Roosevelt (der døde seks uger senere). Churchill var frustreret over, at Roosevelt ikke ville koordinere sin politik med ham, og Roosevelt havde en naiv opfattelse af, at han kunne charmere Stalin på samme måde, som han kunne charmere amerikanske politikere. For Roosevelt var det vigtigste at få Stalin til at acceptere forslaget om oprettelse af FN og få Sovjetunionen ind i krigen mod Japan, der var så omkostningsfuld for USA.
Tankevækkende var Jalta-erklæringens formulering om frie valg ikke blot i Polen, men i alle de befriede lande! Det afgørende var imidlertid ikke, hvad der blev aftalt eller ikke i Jalta, men situationen 'på jorden'. Da de 'tre store' mødtes i Jalta, stod Sovjetunionen med 10 mil. mand i Østeuropa. 17. januar havde de sovjetiske styrker indtaget Warszawa, 10. februar stod marskal Zjukov med sine styrker ved Oder, og 13. februar indtog de sovjetiske styrker Budapest. I hælene på de fremrykkende tropper fulgte sovjetiske og Moskva-trænede østeuropæiske politikere og efterretningsfolk, der fra første færd og i de følgende år satte deres afgørende præg på de 'befriede' stater.

Efter Den Store Fædrelandskrig blev Krim igen et ferieparadis for den sovjetiske elite i tsarens tidligere paladser. Bresjnev foretrak paladset Oreanda, hvor der blev anlagt en swimmingpool med olympiske mål. Fortjenstfulde arbejdere kunne komme på halvøens sanatorier. For mange sovjetborgere var det en sjælden mulighed for under subtropiske forhold at opleve et hav.

Det gjaldt dog ikke tatarerne. Straks efter generobringen blev samtlige Krim-tatarer deporteret til Centralasien, primært Usbekistan, med den begrundelse, at de havde bistået den tyske krigsførelse. Ganske vist havde von Manstein rekrutteret ca. 20.000 tatarer til grupper, der bekæmpede sovjetiske partisaner og tog sig af landsbyers lokalforsvar, men flere end dobbelt så mange tatarer kæmpede i Den Røde Hærs enheder og adskillige blev dekoreret som helte, men heller ikke de undgik den kollektive deportation. Adskillige omkom under transporten østpå.

Samtidig nedgraderedes Krim fra autonom republik til region. Flere end 2.400 tatariske navne for byer og landsbyer, landskaber og bygninger blev fjernet fra kort. Betegnelsen 'Krim-tatar' udgik folketællingsstatistikken og de indgik blot i en samlet opgørelse over 'tatarer'. (Først 
i 1994 blev betegnelsen Krim-tatar igen officielt anerkendt). Krim-tatarerne blev ikke, som en række andre deporterede folkeslag, rehabiliteret efter Nikita Khrusjtjovs 'hemmelige tale' på den 20. partikongres i 1956, hvor han foretog sit delvise opgør med stalinismen. Tatarerne fik ikke lov til at vende tilbage til Krim.

Krim var en del af Den Russiske Socialistiske Føderative Sovjetrepublik. Men i 1954 besluttede Khrusjtjov, at Krim skulle overføres til Den Ukrainske Socialistiske Føderative Sovjetrepublik. Begrundelsen var markeringen af 300-året for Pereiaslav-aftalen mellem en kosakleder og Moskva. Men lige siden har der været spekulationer over, hvad der var de egentlige motiver. En plausibel eller medvirkende forklaring - ud over Khrusjtjovs særlige forhold til Ukraine - er, at Khrusjtjov havde brug for ukrainsk støtte i magtkampen om, hvem der skulle efterfølge Stalin som generalsekretær for Sovjetunionens Kommunistiske Parti.

Umiddelbart var den administrative overflytning af Krim af begrænset betydning, for selvom Sovjetunionen formelt var en forbundsstat, så var det partiledelsen i Moskva, der havde det afgørende ord i alle vigtige sager. Det var først med Sovjetunionens opløsning, at overflytningen fik konsekvenser. For da blev grænserne mellem unionsrepublikkerne til internationale grænser.

Ligesom tidligere havde Krim også strategisk betydning under Den Kolde Krig. Det drejede sig først og fremmest om flådebasen i Sevastopol, men mange nye militære installationer kom til. Blandt de vigtigst var en ubådsbase, der blev sprængt ind i klippen med Balaklava. Basen blev bygget 1953-61, og havde en ca. én km. lang kanal med indog udsejling i hhv. havet og havnen. Den kunne huse 10 ubåde af whisky-klassen eller tilsvarende (med torpedoer med atomsprængladninger) og var bygget til at modstå et atomangreb på 100 kilotons.
Også luftmilitært var Krim en fremragende base for kontrollen over Sortehavet. Der blev bygget flere flybaser, og den 'civile' lufthavn ved Simferopol fik start-og landingsbaner, der klart oversteg det civile behov. Langs sydkysten blev der etableret militære observationsposter og andre anlæg, givetvis til forsvar mod Tyrkiet - den historisk fjende mod syd, der nu var blevet medlem af NATO.

\section{Mineralsekretæren}

Mikhail Gorbatjov er i Vesten først og fremmest kendt for 'glasnost og 'perestrojka', men før det kom i 1985-86 'uskorenje', dvs. fremskyndelse eller acceleration. Et centralt element heri var den anti-alkoholkampagne, der gav Gorbatjov øgenavnet 'mineralsekretæren'. Kampagnen førte til, at marker med gamle vinstokke blev pløjet ned med store økonomiske konsekvenser for vinbønderne. Heldigvis var der lokale partibureaukrater på Krim, der nølede og dermed bidrog til genetablering af vinproduktionen, da anti-alkoholkampagnen blev opgivet pga. de svigtende statsindtægter fra vodkaproduktionen.

Ulykken på atomkraftværket i Tjernobyl i april 1986 blev - efter de indledende forsøg på at dække over katastrofens omfang - begyndelsen på perestrojka og den indtil da begrænsede miljøbevægelse i Sovjetunionen. Efter nogen tid opstod der også en miljøbevægelse på Krim, der dog hurtigt blev kapret af konservative politiske kræfter. Et planlagt byggeri at et atomkraftværk i det nordøstlige Krim blev dog standset.

Der var i det hele taget ikke megen 'perestrojka' på Krim, hvis dominerende ledere var imod politiske og økonomiske reformer. Under kupforsøget i august 1991 mod Gorbatjov, der blev tilbageholdt i den officielle sommerbolig i Foros på Krim, var såvel de lokale ledere som befolkningen stort set passive. Sympatien over for kupmagerne var udbredt.

Men takket være 'glasnost' fik tatarer- 


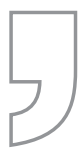

Mikhail Gorbatjov er i Vesten først og fremmest kendt for 'glasnost og 'perestrojka', men før det kom i 1985-86 'uskorenje', dvs. fremskyndelse eller acceleration. Et centralt element heri var den anti-alkoholkampagne, der gav Gorbatjov øgenavnet 'mineralsekretæren'. ne mulighed for at kæmpe åbent for deres krav om at vende tilbage til deres 'Grønne Hjemland' på Krim. Efter nogle større demonstrationer i Moskva blev en kommission sat til at se på sagen, uden at der dog rigtig skete noget. I stedet begyndte tatarerne fra omkring 1989 på eget initiativ at vende tilbage til Krim, og i august fik et begrænset antal tatarer officiel tilladelse til at gøre det. Gorbatjov begrunder i sine erindringer begrænsningen med hensynet til 'den etniske balance' på Krim. Siden er omkring 250.000 tatarer lovligt eller 'ulovligt' vendt tilbage. Mange har ikke opholdstilladelse og lever under kummerlige forhold. Der er en udbredt diskrimination af tatarerne, der også har problemer med at få anerkendt deres politiske rettigheder.

\section{Den tredje belejring af Sevastopol}

Den økonomiske og ikke mindst den politiske situation på Krim var præget af stor ustabilitet i årene efter Ukraines selvstændighed. Økonomisk havde Krim været en af de mere velstående dele af Ukraine, men det ændrede sig brat omkring 1990-91 på grund af Ukraines tiltagende økonomiske kaos. Ligesom resten af Ukraine (og Rusland) var og er Krim plaget af en omfattende korruption, ikke mindst når det drejer sig om handel med jord og fast ejendom samt byggetilladelser. Modstanden mod reelle økonomiske reformer har været udbredt, og som andre steder i det tidligere Sovjetunionen har privatisering skabe såvel formuer som udbredt fattigdom.
Det største politiske stridsemne drejede sig om Krims forfatningsmæssige og folkeretlige status. Krav om øget autonomi var opstået allerede i slutningen af sovjetperioden, men nu blev spørgsmålet om forholdet til henholdsvis Ukraine og Rusland det centrale emne, der overskyggede hensynet til demokratiske og markedsøkonomiske reformer. I årene frem til 1994 voksede de pro-russiske bevægelser og partier sig stærke med (ofte uklart definerede) krav om større autonomi, selvstændighed, 'suverænitet' eller en eller anden form for 'genforening' med Rusland. Deres krav blev støttet at fremtrædende politikere i Rusland, men ikke af Boris Jeltsin. Lederen af 'Den Russiske Bevægelse' på Krim, Jurij Meshkov, blev i januar 1994 valgt med overvældene flertal som Krims præsident. Det blev imidlertid den pro-russiske bevægelses foreløbige højdepunkt.

På den modsatte fløj befandt tatarerne sig. De var og er imod Krims løsrivelse fra Ukraine og indlemmelse i Rusland. I 1991 var de ikke repræsenteret i Krims politiske organer. I stedet organiserede de Krim-tatarens Kurultaj, der erklærede Krim for det Krim-tatariske hjemland. Der valgtes også en Mejlis, et nyt lovgivende og udøvende organ, en parallel (om end yderst svag) magtstruktur. Krims Øverste Sovjet erklærede Kurultais beslutninger for ulovlige.

Det nye styre i Kiev havde ikke nogen klar nationalitets- og regionalpolitik. Den indførte ukrainsk statsborgerskab og forbød dobbelt statsborgerskab. Styret 
ville også gøre ukrainsk til det eneste officielle sprog i Ukraine. Det skabte stor uvilje blandt etniske russere, der betegnede ophævelsen af russisk som officielt sprog som 'Den tredje belejring af Sevastopol'. (Sprog er dog hverken er en entydig etnisk eller politisk markør på Krim). Den manglende mulighed for dobbelt statsborgerskab skabte problemer for de tilbagevendende tatarer, der indtil 1998 have svært ved at blive løst fra deres usbekiske statsborgerskab.

Efter adskillige konflikter og langstrakte forhandlinger mellem Kiev og Simferopol lykkedes det at finde en løsning med betydelig autonomi for Krim. Medvirkende var det, at Meshkovs autoritære stil mødte stigende modstand i Krims parlament. Der opstod interne stridigheder i Den Russiske Bevægelse, hvor nogle (lige som forretningsmænd i andre politiske grupperinger) ønskede bedre forbindelser til styret i Kiev. Ved det ukrainske præsidentvalg i 1994 fik Leonid Kutjma, der førte en mere positiv politik over for Rusland end forgængeren, med sine næsten 90 pct. af stemmerne på Krim langt større tilslutning her end i landsgennemsnittet.

I en opinionsundersøgelse på Krim i 1996 tilkendegav befolkningen, at den så økonomi, social sikring og kriminalitet som halvøens største problemer. Krims politiske status og etniske modsætninger blev kun nævnt halvt så ofte. Den økonomiske krise i Rusland året efter bidrog givetvis også til svækkelsen af de pro-russiske kræfter og nedtoningen af separatisternes krav.

Et centralt konfliktspørgsmål mellem Rusland og Ukraine drejede sig om Sortehavsflåden, basen i Sevastopol og en del anden flådeinfrastruktur langs kysten. I første omgang resulterede forhandlingerne i en aftale om en 50/50-deling af skibene. Ukraines økonomiske problemer førte dog siden til, at Ukraine overdrog 30 pct. af sin del af flåden som afdrag på energigælden til Rusland. I 1997 anerkendte Rusland, at
Sevastopol var ukrainsk og indgik en lejeaftale af basen i 20 år. I foråret 2010 forlængede Ukraines parlament under stor tumult aftalen med Rusland om basen med yderlige 25 år, dvs. til 2042.

\section{Den Orange Revolution}

Den Orange Revolution i 2004 satte sig ikke dybe spor på Krim. Ved omvalget i december efter Ukraines Højesteret havde erklæret det oprindelige valg for ugyldigt, fik Viktor Jusjtjenko kun godt 15 pct. af stemmerne på Krim, mens Viktor Janukovitj, Kutjmas og Vladimir Putins protegé, fik godt 81 pct. Resultatet skuffede de reformvenlige og skabte især frygt blandt tatarerne, der helt overvejende havde stemt på Jusjtjenko. Den udbredte pro-russiske holdninger i befolkningen på Krim kom også til udtryk i en demonstration mod en amerikansk-ukrainsk flådeøvelse i maj 2006 ud for Feodosia.

De tilsyneladende vellykkede autonomiforhandlinger fik nogle forskere til at se Krim som et eksempel på, at etnisknationale problemer, der havde ført til krige andre steder i forbindelse med Sovjetunionens opløsning, lod sig løse gennem forhandling og gensidig hensyntagen. Men den britiske historiker og journalist Anna Reid skrev i 1997: 'Hvis en borgerkrig skulle bryde ud i Ukraine, så ville det mest sandsynlige være, at den begyndte på Krim'.

Den russiske forfatter Vasilij Aksjonov skrev i slutningen af 1970'erne en både morsom og tankevækkende kontrafaktisk roman om Krim. Udgangspunktet er, hvordan det kunne være gået, hvis Krim ikke var en halvø, men en $\emptyset$, hvor 'de hvide' under Borgerkrigen havde holdt stand mod bolsjevikkerne og skabt deres egen 'stat'. Som Taiwan i forhold til Den Kinesiske Folkerepublik. Bogen kunne naturligvis ikke udkomme i Sovjetunionen, men først i 1981 på engelsk, da Aksjonov var emigreret til USA. 
I bog er det selvstændige Krim er en brølende kapitalistisk stat med motorveje, skyskrabere, bugnende indkøbscentre, tabloidaviser og bordeller. I slettelandet er der et driftigt landbrug, der eksporterer til udlandet. Østkysten ved Det Asovske Hav er domineret af olieindustri. Befolkningen består af veteraner fra borgerkrigen og deres efterkommere samt tatarer, gæstearbejdere og tilflyttere fra nær og fjern. Det politiske liv er broget med omkring 40 politiske partier. I dette kaos opererer også KGB, CIA og Krims egen efterretningstjeneste i et uigennemskueligt dobbeltspil.

Hovedpersonen, Andrej Lutjnikov, en playboy og søn af en af øens millionærer og ledende veteran fra Borgerkrigen, er chefredaktør for 'Den Russiske Kurer', øens førende avis. Han er imidlertid også leder af bevægelsen 'Fælles Skæbne', der arbejder for en sammenslutning med 'Moderlandet'. Han tror, at Krim på denne måde vil kunne bidrage til at reformere Sovjetunionen.

Sådan ser man imidlertid ikke på det $\mathrm{i}$ kommunistpartiets Politbureau i Moskva, en kynisk gruppe Bresjnev-lignende geronder. De frygter den ideologiske smitte fra kapitalisterne og veteranerne på Krim. Så da det politiske parti, der er udgået af 'Fælles Skæbne', vinder Duma-valget på Krim og indleder forhandlinger om en gradvis tilnærmelse mellem Krim og Sovjetunionen, slår Moskva til.

En tidlig maj-morgen gennemfører de sovjetiske væbnede styrker, under påskud af en øvelse, operation 'Forår'. Fra landgangsfartøjer strømmer kampvogne og pansrede mandskabsvogne ind på kysten, mens kampfly og -helikoptere på vej for at besætte Krims militærbaser fylder luften. De sovjetiske styrker modtages med hyldest i gaderne, mens veteraner anholdes, og tatarerne frygter for deres fremtid.

I bogens næstsidste scene ankommer det sovjetiske helikopterhangarskib 'Kiev' til Sevastopol, hvor det langsomt glider forbi Skt. Vladimir Katedralen og ind i havnen, mens admiralen studerer listen over de indkøb, han planlægger at foretage på Krim. På en missilbase, hvorfra man kunne ramme 'Kiev', sidder basens kommandant og den sovjetiske oberst, der har indtaget den, og skåler i whisky.

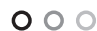

